\title{
Possibilities of Var Application in Financial Investments
}

\author{
Boris Kollár ${ }^{1, *}$, Peter Adamko \\ ${ }^{1}$ University of Zilina, FPEDAS, department of economics Univerzitná 1,010 26 Žilina, Slovakia \\ ${ }^{2}$ University of Zilina, FPEDAS, department of quantitative methods and economic informatics \\ Univerzitná 1,010 26 Žilina, Slovakia
}

\begin{abstract}
Value at Risk is one of the quantitative methods used in banking and insurance. It is basically a statistical estimate of the worst loss that may occur with a certain probability in a certain future period. The main aim of this paper is application of Value at Risk model to the problem of optimal portfolio creation. It focuses on banking sector in Slovak republic and uses Value at Risk to assess the risk of commercial bank sector in Slovakia. To achieve this goal, it uses several methods of formal logic like analysis, synthesis, deduction, comparison as well as statistical methods. The first part is dedicated to a description and characterization of Value at Risk. Second part is oriented on characteristics of Slovak banking sector. Results consist of application of Value at risk on five biggest commercial banks in Slovakia. The conclusion of this paper is focused on the sets of recommendations for Value a Risk application and possible source of problems, which could occur while applying it under the conditions of small economy and its banking sector.
\end{abstract}

\section{Introduction}

The origins of the Value at Risk method dates back to the mid-20th century, but it took on its current form - and its name - in the early 1990s when Dennis Weatherstone, chairman of investment bank J.P. Morgan, asked his subordinates to produce on a daily basis a "simple report" on the risks and losses that the bank may be exposed to in the next 24 hours. The method they developed was called Value-at-Risk and it was initially used only by J.P. Morgan. With the use of this method, senior management have been able to better understand the risks bank has taken, and this contributed to improvement of the capital allocation within the bank. In 1993, it was presented at a conference on risk management, and their modified version was developed, published and presented to general public under the name RiskMetrics later. Although the idea was not quite original, but it has expanded and popularized globally the original thought.

The Value at Risk method estimates the largest loss that can occur with a prescribed probability in the future. It is one of the most commonly used approaches within the socalled. internal models for calculating capital requirements for market risk in the banks.[1]

\footnotetext{
*Corresponding author: boris.kollar@fpedas.uniza.sk
} 
Given that market-making functions inevitably lead to market risk, various restrictions on trading have been introduced to limit the extend of this risk. Until the 1990s, these limits were in the form of restrictions on:

1. the size of the open net positions

2. maturity mismatch rates in a net position

3. the permitted level of negative gamma value in option's positions

4. exposure to volatility changes

These limits have introduced a comprehensive set of restrictions on trading positions. Their effective usage was very demanding to put in practice, because risk exposures often changed rapidly in response to market developments. The information and management systems of that time also led to the application of these limits in parts with different inconsistencies and several other adverse effects: "good" risks were often ignored, because there a risk of arbitrage occurred, decisions were made with insufficient risk analysis and risk reduction in one segment occasionally led to an increase of risk in another. Perhaps the most important shortcoming of the old method was the absence of an integrated risk management system.

There was a very small link between the limitations structure and the range of potential loss that might have occurred. The management units in charge of approving these options were often reliant on data obtained from specialists. Even these specialists have had a major problem in interpreting these limitations into measurable data, not yet to provide an effective integrated risk management system.[2]

Gradually, consensus emerged, which was a fundamental interest for all concerned institutions. Namely it was the distribution of the potential loss probability from a trading position, regardless of the exact structure of these positions. This concept then evolved into Value at Risk. This gave the management of financial institutions more consistent ways to determine acceptable levels of risk within the formal limits in which traders operated.[3] Of course, there was still a strong reliance on market risk specialists, to determine market dynamics and trading positions in possible risk estimations, but the VaR method allowed to define limitations, that reflected the attitude to risk in a way, that previous system was not able to do.[4]

Thus, one of the most significant benefits of VaR, was to improve the quality of risk management across the enterprise. The main idea behind the VaR concept is to replace the maximum loss with the maximum loss, which should not be exceeded with given probability rate $\alpha \epsilon(0,1)$. The value-at-risk portfolio with chosen probability rate $\alpha$ is given by the smallest number $l$, such that the probability of loss $L$ exceeding $l$ is not more than $(1-\alpha)$, thus [5]:

$$
\begin{gathered}
V a R_{\alpha}=\inf \{l \in \mathbb{R}: P(L>l) \leq 1-\alpha\} \\
V a R_{\alpha}=\inf \left\{l \in \mathbb{R}: F_{L}(l) \geq \alpha\right\},
\end{gathered}
$$

where $F_{L}(l)$ is distribution function of losses.

\section{Methodology}

Commercial bank is essentially a business entity of a specific nature. Compared to other business entities from other sectors of the economy, it has a number of peculiarities and specific features, that affect its position and overall importance in the economy.

For a commercial bank, the ultimate goal is to maximize its profit. At the same time, it is obliged to observe the principles of security and stability in terms of banking business risks. 
It can be characterized as a financial intermediary, which focuses mainly on the movement of funds between entities. Intermediation is based on receiving deposits and lending from these deposits.[6]

The main problem of managing a commercial bank is to reconcile banking objectives liquidity, profitability and solvency - and these objectives are in conflict with each other. If the bank is smoothly liquid (it keeps its assets in the form of cash), it is unable make a profit. If it provides more risky loans (it makes a profit), it increases the risk of possible bankruptcy. Asset and liability management is therefore very important for the management of a commercial bank.[7]

At present, there is a central bank - National Bank of Slovakia and 14 commercial banks based in the Slovak Republic. The biggest 10 commercial banks according to total assets as of 2017 are in the following table 1 .

Table 1. Total assets of biggest Slovak banks.

\begin{tabular}{|l|r|r|}
\hline \multicolumn{1}{|c|}{ Bank } & Total assets & \multicolumn{1}{c|}{ Share } \\
\hline Slovenská sporitel'ňa, a.s. (SLSP) & $15567681 €$ & $23,32 \%$ \\
\hline Všeobecná úverová banka, a.s. (VUB) & $14235367 €$ & $21,33 \%$ \\
\hline Tatra banka, a.s. (TB) & $11545709 €$ & $17,30 \%$ \\
\hline Československá obchodná banka, a.s. (CSOB) & $7807401 €$ & $11,70 \%$ \\
\hline $\begin{array}{l}\text { UniCredit Bank Czech Republic and Slovakia, } \\
\text { a.s. (UCB) }\end{array}$ & $5297343 €$ & $7,94 \%$ \\
\hline Poštová banka, a.s. (PB) & $4242589 €$ & $6,36 \%$ \\
\hline Prvá stavebná sporitelňa, a.s. (PSS) & $2905035 €$ & $4,35 \%$ \\
\hline Prima banka Slovensko, a.s. (PBS) & $2310814 €$ & $3,46 \%$ \\
\hline Sberbank Slovensko, a.s. (SB) & $1420083 €$ & $2,13 \%$ \\
\hline OTP Banka Slovensko, a.s. (OTP) & $1413346 €$ & $2,12 \%$ \\
\hline Sum & $66745368 €$ & $100 \%$ \\
\hline
\end{tabular}

The favourable economic situation prevails in Slovakia for some time. Despite the fact that the indebtedness of the Slovaks is slowly increasing, the volume of defaulted household loans is declining.[8] According to the National bank of Slovakia (NBS), loan is considered to be defaulted, when the borrower is late in paying for more than 90 days, or a loan when the bank considers the borrower unlikely to meet his obligation without realizing the collateral. According to NBS, the share of defaulted household loans has been gradually declining for 3 years. While twenty years ago, every thirteenth borrowed euro was delayed, these days it is up to every twenty-ninth borrowed euro. The smallest percentage of nonperforming loans is the repayment of real estate loans and the highest reimbursement of consumer loans.[9]

Last year, Slovak banks earned more than expected. This happened despite the low interest rates. The banking sector's net profit reached almost EUR 612 million in 2017, which rightly ranks among the most successful years, although only a few of the largest banks produced this profit.[10]

\section{Results}

To assess potential risk of banking sector in Slovakia, we decided to create portfolio of the biggest banks in Slovakia. To make this estimate more accurate we decided to take only five biggest Slovak banks into this portfolio. We started from the table 1. We take into this 
portfolio only banks with significant market share. Therefore, we set the trash hold to get into our portfolio on $5 \%$. Poštová banka, a.s. was excluded, because the owner of this bank is state and therefore it is not possible to get its accurate market value. The next step was to look at the market value of this banks. All of them are daughters of bigger foreign banks. Because of the fact, that these daughters are not daily traded on a liquid market, we looked at the market values and share prices of their mother banks. On the base of this variables and market shares from table 1, we created our portfolio which should represent current banking sector in Slovak republic. We assigned weights subsequently, as we can see in the table 2.

Table 2. Individual weights of banks in portfolio.

\begin{tabular}{|l|l|l|}
\hline Mother bank & Symbol & Weihts \\
\hline Erste Group Bank AG (SLSP) & EBS.VI & 0,2858894 \\
\hline Intesa Sanpaolo S.p.A. (VUB) & ISP.MI & 0,2614224 \\
\hline Raiffeisen Bank International A.G. (TB) & RBI.VI & 0,2120288 \\
\hline KBC Group N.V.(CSOB) & KBC.BR & 0,1433774 \\
\hline UniCredit S.p.A. (UCB) & UCG.MI & 0,097282 \\
\hline Sum & & 1 \\
\hline
\end{tabular}

The next step is to calculate Value at Risk values for individual companies and for the whole portfolio using weights from table 2 . To get better look at this problematic, we calculated Value at Risk wit the use of different distributions.[11] Namely normal distribution, modified normal distribution and Gauss distribution. The difference in these distributions is in their tails, skewness, kurtosis and means. We decided to use as an example one day Value at Risk with confidence level at $95 \%$.

Following table 3 and figure shows the Value at Risk results for individual companies in our portfolio and portfolio as a whole.

Table 3. VaR95 values for individual companies and portfolio using different distributions.

\begin{tabular}{|l|l|l|l|l|l|l|}
\hline Distribution & EBS.VI & ISP.MI & RBI.VI & KBC.BR & UCG.MI & Portfolio \\
\hline Historical & 0.02442714 & 0.02060206 & 0.02211316 & 0.02419877 & 0.03564025 & 0.02041391 \\
\hline Gauss & 0.02432492 & 0.02178367 & 0.02526754 & 0.02569986 & 0.03528539 & 0.02074545 \\
\hline Modified & 0.02507616 & 0.01915134 & 0.02357893 & 0.02333768 & 0.03579331 & 0.02033097 \\
\hline
\end{tabular}

From the results presented in table 3 and figure 1, we can see, that UniCredit S.p.A. (UCG.MI) which is mother bank of Slovak daughter UniCredit Bank Czech Republic and Slovakia, a.s. generates worst results of all banks in portfolio. In the worst-case scenario, with confidence level of $95 \%$, the stock return will be around - 3,5\%. All three distributions generate similar results. The best results and therefore the smallest loss in returns at given confidence level were obtained by Intesa Sanpaolo S.p.A. ant therefore its Slovak daughter VUB. It is the case for all used distributions. Gauss distribution offered slightly different rank for Erste Group Bank AG, which is mother of Slovak SLSP bank. Overall results for all three distributions are similar. We can clearly see, that Value at Risk portfolio generates lower possible losses at given confidence level of 95\%. Slovak banking sector has therefore good structure in terms of its commercial banks mothers, because it manages to lower potential loss in asset returns in worst case scenario. The only exception is the Value at Risk for Intesa Sanpaolo S.p.A., which in the case of modified distribution has lower percentage of maximum loss than portfolio. 


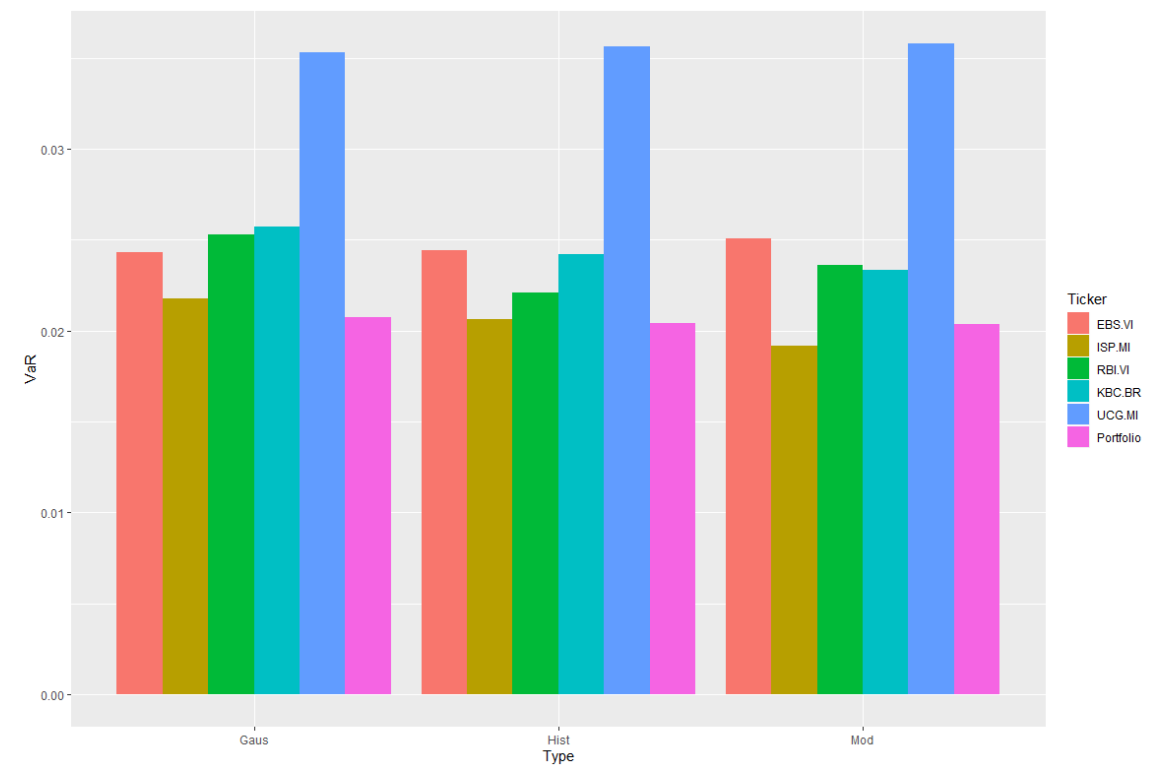

Fig. 1. Value at Risk values for our portfolio and individual companies

\section{Conclusion}

The results of Value at risk application on Slovak banking sector showed, relatively good values. It confirms, that banking sector and foremost the mothers of Slovak banks have relatively low risks of financial losses in short time.

This paper offers just one of many possible applications of Value at Risk in financial investments. Investors make financial investment decisions based on three criteria: return, risk and liquidity.[12] Risk management is an area that has close attention not only by academics, but also by professionals. There are many measures of risk for managers to use for optimization of their portfolio. The main approach nowadays is not to optimize portfolio with focus based on volatility, but to minimize the risk of losses as empirical studies have shown that investors are more vulnerable to losses than to profits [13]. The basic measure for portfolio losses, is Value at Risk. This method however has certain shortcomings and some of them have already been overcome by Conditional Value at Risk.

We hope that this paper will provide the lender with a sufficient overview of the possible Value at Risk usage, risks and methods of its calculation. A possible extension of this work would be consideration of Conditional Value at Risk calculation, several other distributions used in financial investments, conditional loss distribution and subsequent dynamic risk management.

The paper is an output of the science project VEGA 1/0428/17 Creation of new paradigms of financial management at the threshold of the 21 st century in conditions of the Slovak republic.

\section{References}

1. P. Kral, K. Janoskova, Condition Of Acceptability Of Project Risk In Management Of The Project Portfolio, In: 15th International Scientific Conference on Globalization and its Socio-Economic Consequences, Rajecke Teplice, 345-352 (2015) 
2. S. Manganelli, R. F. Engle, Value at Risk Models in Finance, ECB Working Paper n.75/2001, 41 (2001)

3. A. Ch-M. Yeo, S. Carter, A. Ch. Nurhidayah, Corporate Social Responsibility Intervention: A Catalyst to Small-Medium Enterprise Employee Engagement, Psychosociological Issues in Human Resource Management 6(1), 38-62., (2018)

4. B. Gavurova, M. Packova, M. Misankova, L. Smrcka, Predictive potential and risks of selected bankruptcy prediction models in the Slovak business environment. Journal of Business Economics and Management, 18, 6, 1156-1173 (2017)

5. P. Embrechts, R. Frey, A. J. McNeil, Quantitative Risk Management: Concepts, Techniques and Tools, (Princeton University Press, New Jersey, 2005)

6. V. G. Ignatyev, I. NurtdinovIlgiz, The features of regional investment analysis in relation to the corporate sector of economy in conditions of globalization, Ekonomickomanazerske spektrum, 12(1), 75-82 (2018)

7. J. Oláh, S. Kovács, Z. Virglerova, L. Lakner, . Popp, Analysis and Comparison of Economic and Financial Risk Sources in SMEs of the Visegrad Group and Serbia, Sustainability, 11(7), 1853, 1-19 (2019)

8. W. Kisiala, K. Suszynska, Economic growth and disparities: an empirical analysis for the Central and Eastern European countries. Equilibrium - Quarterly Journal of Economics and Economic Policy, 12(4), 613-631 (2017)

9. M. Hudáková, J. Dvorský, Assessing the risks and their sources in dependence on the rate of implementing the risk management process in the Slovak SMEs. Equilibrium Quarterly Journal of Economics and Economic Policy, 13, 3, 543-567 (2018)

10. http://www.nbs.sk/_img/Documents/_Publikacie/BulletinMFS/2017/BulletinMFS_062 017.pdf

11. P. Adamko, E. Spuchlakova, K. Valaskova, The history and ideas behind VaR. Procedia Economics and Finance, 24, 18-24 (2015)

12. A. Thiele, The Independence of the ECB: Justification, Limitations and Possible Threats, Journal of Self-Governance and Management Economics, 6(1), 98-121 (2018)

13. K. Valaskova, V. Bartosova, P. Kubala, Behavioural Aspects of the Financial DecisionMaking. Organizacija, 52, 1, 22-32 (2019)

14. P. F. Christoffersen, Evaluating Interval Forecasts, University of Pennsylvania: Internal Economic Review, 39, 4. 1998. 23 (1998)

15. E. Zimková, Riadenie komerčnej banky. Vybrané kapitoly (Banská Bystrica: Univerzita Mateja Bela v Banskej Bystrici, Ekonomická fakulta, 2010) 